Vol. 51, n. 5 : pp.929-935, September-October 2008 ISSN 1516-8913 Printed in Brazil
BRAZILIAN ARCHIVES OF BIOLOGY AND TECHNOLOGY

AN INTERNATIONAL JOURNAL

\title{
Histopathological, Immunohistochemical and Ultraestructural Evaluation of Inflammatory Response in Arius genus Fish under Experimental Inoculation of BCG
}

\author{
Ricardo Yuji Sado ${ }^{1 *}$ and Eliana Reiko Matushima ${ }^{2}$ \\ ${ }^{1}$ Setor de Piscicultura; Escola Superior de Agricultura "Luiz de Queiroz"; Universidade de São Paulo; Av. Pádua \\ Dias 11; C.P.: 09; ricardo_sado@yahoo.com; 13418-900; Piracicaba - SP - Brasil. ${ }^{2}$ Departamento de Patologia; \\ Faculdade de Medicina Veterinária e Zootecnia; Universidade de São Paulo; Av. Orlando Marques de Paiva 87; \\ Cidade Universitária; São Paulo - SP - Brasil
}

\begin{abstract}
The aim of this study was to evaluate the inflammatory response kinetics after experimental inoculation with BCG in the primitive Arius sp. fish. The BCG was applied through the intramuscular injection in the caudal peduncular region, and the samples were collected for the analyses at days 1, 3, 7, 14, 21, and 33 post-injection. Acute phase inflammatory infiltrate was characterized by the predominant mononuclear cells, intersticial edema, and muscular tissue necrosis. As the inflammatory response evolved, a large number of multinuclear giant cells were formed containing the BCG. These giant cells were positive for the S100 protein at the histochemical analysis, which demonstrate the macrofage activity, confirmed by the ultra-structural analysis showing the lack of the cytoplasmic membrane enveloping the many nuclei within the giant cell. These results led to the conclusion that Arius sp. fish injected with the BCG showed a difuse inflammatory response characterized by a large number of mononuclear cells, absence of granuloma formation, and predominant giant cells.
\end{abstract}

Key words: Fish, Arius, phylogeny, BCG, inflammation, giant cells

\section{INTRODUCTION}

Teleostean fish may be phylogenetically divided into three groups: primitive, intermediary, and modern fish. Arius sp. fish are considered primitive, and belong to the Cypriniform order, Siluroidei sub-order (Gosline, 1971). Based on Darwin's evolutionary theory, Metchnikoff (1968) studied the inflammatory response in species from different metazoan phyla, classes, and orders, and proposed that the complexity of this response accompanie the evolution. In fishes this complexity may also be observed when studying the chronic response to the inflammatory stimuli in various species belonging to different groups (primitive, intermediary, and modern). In most primitive teleostean fish, a large number of the giant cells form around the pathogenic agent as the response develops (Albernethy and Lund, 1978, Goodwin and Grizzle, 1991, Xavier and Matushima, 1993, Goméz, 1998). Multinuclear giant cell formation in the chronic inflammatory response in the primitive fish is similar to that observed in the superior vertebrates (Goméz, 1998). Although the inflammatory response has been extensively studied among the exothermic vertebrates, huge gaps of the knowledge are still present. Therefore, this study aimed to

\footnotetext{
*Author for correspondence
} 
characterize the inflammatory response in the primitive Arius sp. fish after the experimental induction of inflammation in the histopathological, immunohistochemical, and ultraestructural levels.

\section{MATERIALS AND METHODS}

\section{Animals}

A total of 52 Arius sp. fishes with an average length of $22.31 \mathrm{~cm}$ were collected using line and hook at the Bertioga canal in SP, Brazil, and divided into six study groups and one control group. The animals were kept at the ACQUA MUNDO - Aquário do Guarujá, Brazil, in the round water tanks with a total capacity of $1000 \mathrm{~L}$ under constant aeration and water exchange every alternate day.

\section{Experimental intervention}

The animals were anesthesized through the immersion in a 1:10000 benzocaine solution in the alcohol (Ferreira et al., 1979). Following the anesthesia, $0.05 \mathrm{~mL}$ of the $8 \mathrm{mg} / \mathrm{mL}$ BCG (Calmette bacillus - Guerrin) vaccine, obtained from the Butantã Institute (SP, Brazil) was injected intramuscularly in the caudal peduncular region, above the lateral line in the right side. Following the injection, the animals were returned to the tank, where normal behaviour was recovered after 5 minutes. The muscular fragments were collected at days 1, 3, 7, 14, 21, and 33 postinoculation as described by Matushima (1994). Briefly, the animals were sacrificed in a supersaturated benzocaine solution and the muscular tissue fragments were collected from the inoculation site using a scalpel blade and immediately fixed in a $10 \%$ formaldehyde solution for subsequent histopathological and immunohistochemical analysis.

\section{Histopathology}

After the $24 \mathrm{~h}$ fixation period in $10 \%$ formaldehyde, the samples were processed and stained by the Hematoxylin-Eosin (HE) technique and mounted in a microscope slide under a coverslip (Luna, 1992). The slides were viewed under the optic microscopy at 40, 100, 200, 400, and 1,000X magnification.

\section{Immunohistochemistry}

Fixed samples were suspended in the paraffin and 5 micron cuts were mounted onto the slides previously treated with $4 \%$ sylane in acetone. The slides were then incubated in primary antibody buffer with either $M$. bovis - BCG (1:10,000 Dako A/S,Denmark), AE1/AE3 cytokeratin (1:800, Dako A/S, Denmark), or S100 (1:15000, Dako A/S, Denmark) antibodies.

\section{Electron Microscopy}

The muscular tissue fragments collected at days 14,21 , and 33 were fixed in a $2 \%$ glutaraldehyde in Milloning buffer solution for subsequent processing and viewing under the transmission electron microscopy.

\section{RESULTS}

\section{Histopathology}

At day 1 post-inoculation, a diffuse inflammatory response comprised of mainly the mononuclear infiltrates, intersticial edema, and muscular necrosis was observed. As days post-inoculation increased, a large number of the phagocytic mononuclear cells were observed, as well as a progressive increase in the multinuclear giant cells characterized by a large cytoplasm containing the agent (Fig. 1). After 21 days post-inoculation, no reaction changes were observed, maintaining a difuse inflammatory response at the site of the lesion, with a mononuclear infiltrate and a large number of multinuclear giant cells. Although the lesion did not organize into a granuloma, a tendency towards its retreat was observed, because the intersticial edema, hemorrhagic sites, and tissue necrosis decreased, besides the presence of many giant cells around the BCG deposits (Fig. 2).

\section{Immunohistochemistry}

All the slides were positive for the BCG at all the experimental times, initially diffused, then defined to the interior of the multinuclear giant cells (Fig. 3). S100 was also found in all the slides, which demonstrate the presence of the macrophage cells in the site of the lesion (Fig. 4). On the other hand, all the slides were negative for the AE1/AE3 cytokeratin, which in turn demonstrated that the macrophages did not differentiate into cytokeratin excreting epithelyoid cells (Fig. 5). 


\section{Ultraestructure}

The multinuclear giant cell ultraestructure analysis demonstrated the presence of many nuclei without a cytoplasmic membrane enveloping each one, which showed that all belonged to a same cell (Fig. 6).

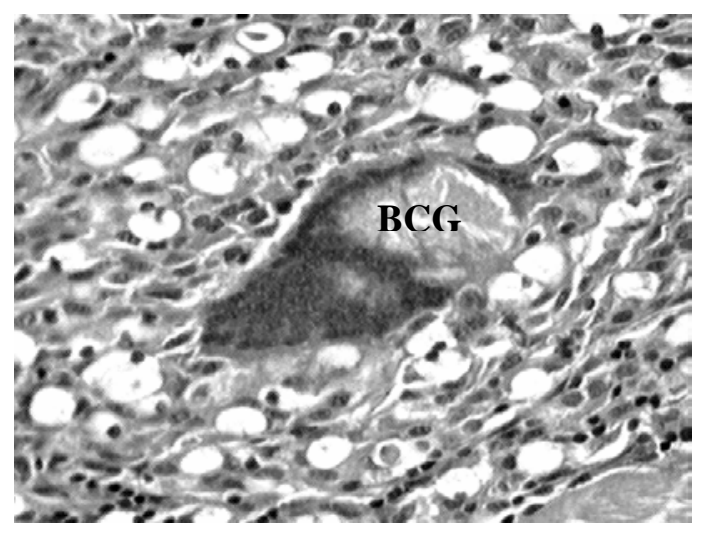

Figure 1 - Photomicrography of Arius sp. muscle tissue at day 7 post-inoculation. Multinuclear giant cell with BCG in its interior. HE X 400.

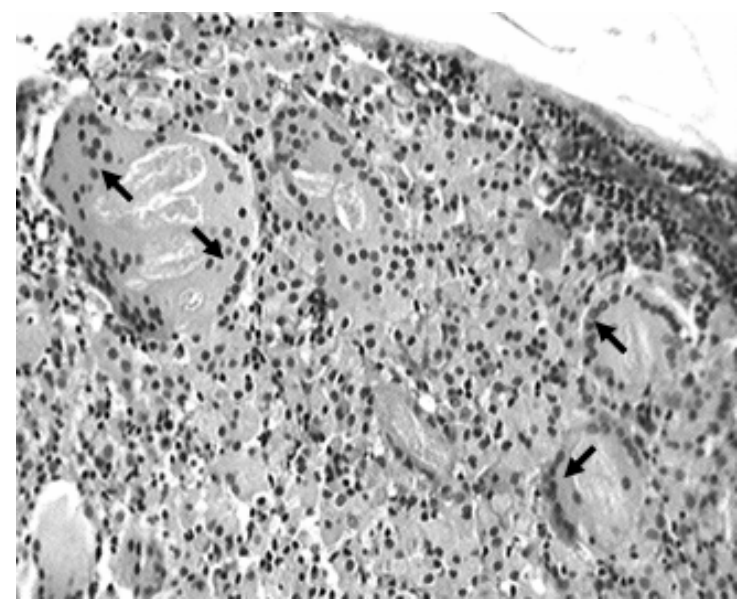

Figure 2 - Photomicrography of Arius sp. muscle tissue at day 33 post-inoculation. Many giant cells (arrows) containing BCG. HE X 200. 


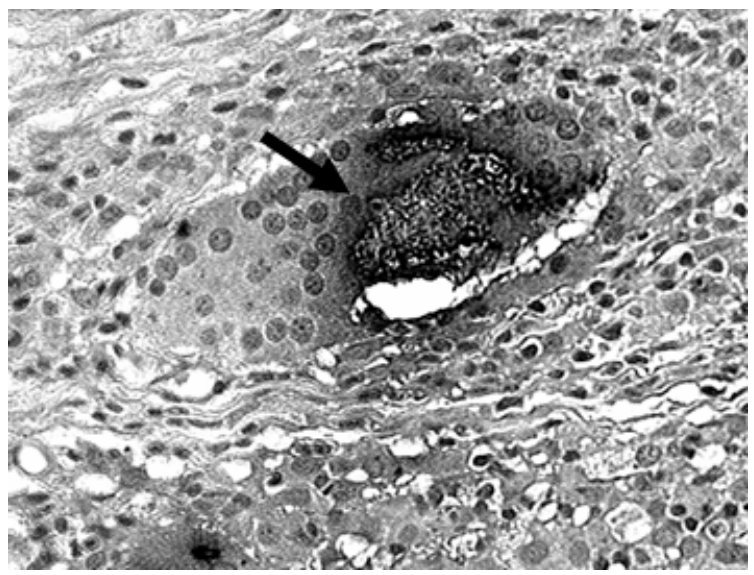

Figure 3 - Photomicrography of Arius sp. muscle tissue. The arrow indicates immunohistochemical positivity for BCG inside a giant cell. ABC X 400 .

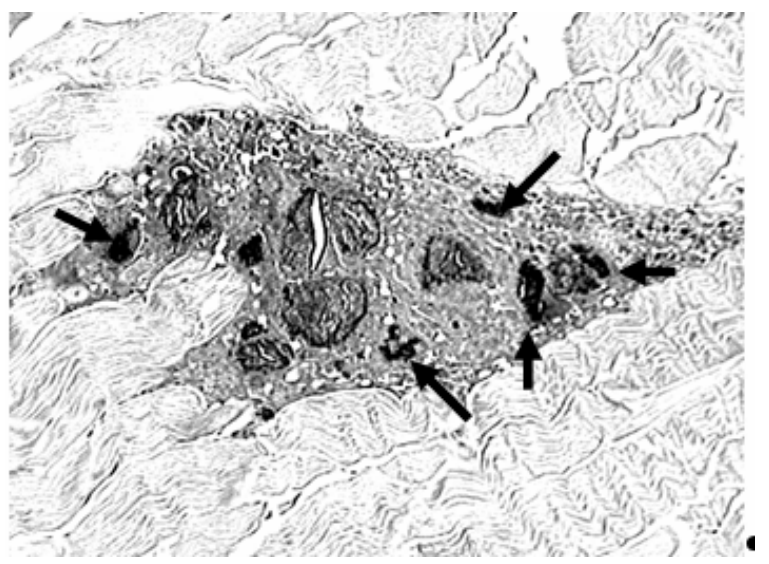

Figure 4 - Photomicrography of Arius sp. muscle tissue. The arrows indicate immunohistochemical positivity for S100. ABC X 100.

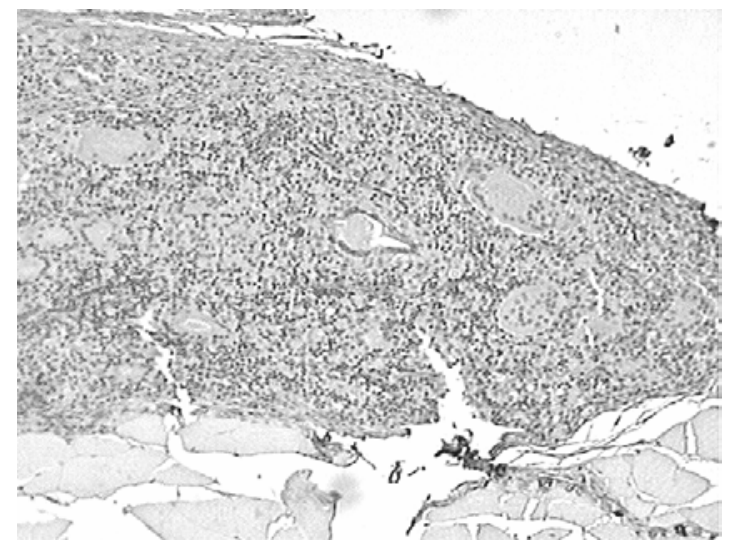

Figure 5 - Photomicrography of Arius sp. muscle tissue. The absent of darkness demonstrate immunohistochemical negativity for AE1/AE3 cytokeratin. ABC X 100. 


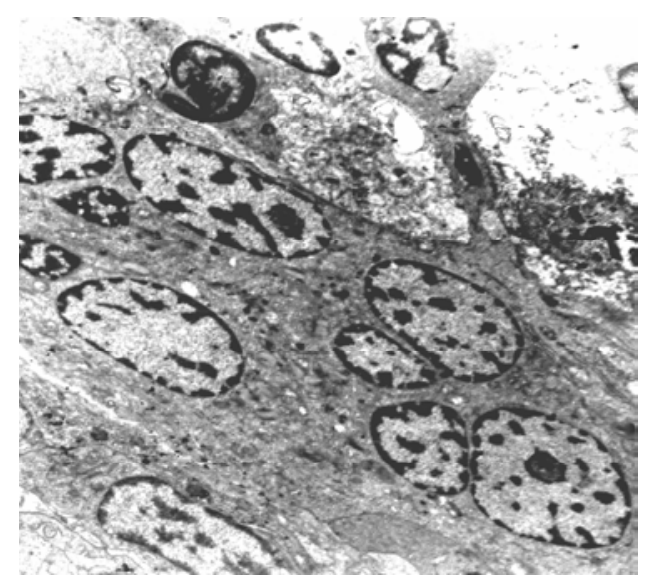

Figure 6 - Ultraestructural photomicrography of Arius sp. muscle tissue. No cytoplasmic membrane enveloping each nucleus. X 11.200.

\section{DISCUSSION}

In the primitive fish species, a diffuse inflammatory response comprised mainly of the giant cells, without granuloma formation and without differentiation of the macrophages into the epithelyoid cells (Goodwin and Grizzle, 1991; Xavier and Matushima, 1993; Goméz, 1998; Talaat et al., 1999; Howard and Byrd, 2000) negative for the cytokeratin expression - is observed. In this study, both the morphological and cellular differences were observed during inflammatory response. At the day 1 postinoculation of BCG, the process was characterized as a diffuse inflammatory response with the mononuclear infiltrates, interstitial edema and the sites of tissue necrosis, which agree with the study by Finn and Nielsen (1971).

The intense peri-vascular inflammatory response observed in other studies (Finn and Nielsen, 1971; Nash et al., 1986; Matushima, 1994) was also observed in this study and was indicative of the macrophage migration towards the lesion site. During the experiment, the morphological alterations were observed in the phagocytic cells, such as differentiation into the multinuclear giant cells and this process was time-dependent. The multinuclear giant cell presence was demonstrated in the inflammatory response in the primitive fish in the previous studies also (Albernethy and Lund, 1978; Goodwin and Grizzle, 1991; Pulsford and Matthews, 1991; Xavier and Matushima, 1993; Goméz, 1998; Talaat et al., 1999; Howard and Byrd, 2000). Although some sort of organization of this lesion was shown, mainly due to the absorption of the BCG into these giant cells, the lesion did not evolve into a granuloma and maintained a diffuse aspect. In Arius sp. Fish, this was discordant with other authors (Finn and Nielsen, 1971; Huizinga and Nadakavukaren, 1997; Goméz, 1998; Talaat et al., 1999; Howard and Byrd, 2000) who demonstrated the formation of an organized granuloma formed by the differentiation into the epithelyoid cells during inflammatory response in the primitive fish.

The positivity to the anti-BCG antibody found in this study was also demonstrated by Radhakrishman et al. (1991), Matushima (1994), Carabias et al. (1998) and Rego (1999). In the same manner, positive signals for the anti-S100 antibody, demonstrated in all the experimental times in this study, was also demonstrated by Rego (1999) in Poecilia sp. fish, phylogenetically classified as the intermediary (Gosline 1971), and in mammalian granulomas formed by the epithelyoid cells (Falk et al., 1988; Muller and Takeshita, 1991; Momotani et al., 1993). The negative response towards the anti AE1/AE3 cytokeratin was also expected, since the histopathological analysis did not show the formation of keratin-secreting epithelyoid cells (Noga et al., 1989; Matushima, 1994). The ultraestructure analysis of the multinuclear giant cells showed various nuclei without a cytoplasmic membrane division between them and this was in agreement with Mariano (1972).

The fact that some primitive fish produce the epithelyoid cells (Finn and Nielsen, 1971; 
Huizinga and Nadakavukaren, 1997; Goméz, 1998; Talaat et al., 1999; Howard and Byrd, 2000) led to speculate that these species were phylogenetically closer to the intermediary fish and were thus beginning to produce similar responses to the inflammatory stimuli, such as the macrophage characteristics, but did not yet possessed sufficient cellular differentiation in order to produce the morphological and functional traits usually found in the epithelyoid cells, such as the presence of desmosomes between the adjacent cells and positivity to the anti-AE1/AE3 cytokeratin antibody.

\section{CONCLUSION}

Following the intramuscular inoculation with the BCG, Arius sp. fish, phylogenetically classified as primitive, produced a diffuse inflammatory response characterized mainly by the mononuclear infiltrated and an increase in the multinuclear giant cells, without, however, organization into an inflammatory granuloma.

\section{ACKNOWLEDGEMENTS}

The authors wish to acknowledge the Experimental and Comparative Pathology Graduate Program from the Department of Pathology, School of Veterinary Medicine and Animal Science, University of Sao Paulo, ACQUA MUNDO - Aquário do Guaruja, Brazil, The School of Medicine, University of Sao Paulo, The Butantã Institute, The Adolfo Lutz Institute, and FAPESP.

\section{RESUMO}

Avaliou-se a cinética da resposta inflamatória induzida experimentalmente com BCG em peixes primitivos pertencentes ao gênero Arius. Os animais foram inoculados com BCG por via intramuscular na região do pedúnculo caudal, sendo realizada a coleta do material nos tempos experimentais de $1,3,7,14,21$ e 33 dias pósinoculação. A fase aguda da resposta inflamatória se mostrou na forma de infiltrado inflamatório composto predominantemente por células mononucleares, edema intersticial e necrose de tecido muscular. À medida que o processo se desenvolveu, houve formação e aumento no número de células gigantes multinucleadas envolvendo o inóculo. Essas células gigantes, ao exame imunohistoquímico, apresentaram positividade à proteína $\mathrm{S} 100$ indicando ação de células macrofágicas, além da ultraestrutura apontar a ausência de membrana citoplasmática entre os inúmeros núcleos presentes nas células. Em vista dos resultados obtidos podemos concluir que em peixes pertencentes ao gênero Arius sp. inoculados com BCG, verificou-se durante todo tempo experimental uma resposta inflamatória difusa composta predominantemente por células mononucleares, não havendo a formação granuloma, porém havendo o predomínio de células gigantes.

\section{REFERENCES}

Abernethy, C. S. and Lund, J. E. (1978), Mycobacteriosis in mountain whitefish (Prosopium williamsoni) from the Yakima River. Journal of Wildlife Disease., 14(3), 333-336.

Carabias, E.; Palenque, E.; Serrano, R.; Aguado, J. M. and Ballestin, C. (1998), Evaluation of an immunohistochemical test with polyclonal antibodies raised against mycobacteria used in formalin-fixed tissue compared with mycobacterial specific culture. Acta Pathologica, Microbiologica, et Immunologica Scandinavica., 106(3), 385-388.

Falk, S.; Takeshita, M. and Stutte, H. J. (1988), Epithelioide granulomatosis with initial and predominant manifestation in spleen. Morphological and immunohistoquemical analysis of six cases. Virchows Archiv. A, Pathological Anatomy and Histophatology., 414(1), 69-76.

Ferreira, J. T.; Smith, G. L.; Schoonde, H. J. and Holzapfel, C. W. (1979), Comparison of anesthetic potency of benzocaine hydrochloride and MS-222 in two freshwater fish species. The Progressive Fish Culturist., 41(3), 161-163.

Finn, J. P. and Nielsen, N. O. (1971), The inflammatory response of rainbow trout. Journal of Fish Biology., 3, 463-478.

Goméz, S. (1998), Unusual morphopathological features in case of fish tuberculosis. Journal of Fish Diseases., 21(3), 137-141.

Goodwin, A. E. and Grizzle, J. M. (1991), Granulomatous inflammation and monstrous giant cells in response to intraperitoneal hormone implants in channel catfish (Ictalurus punctatus). Journal of Comparative Pathology., 104(2), 149-160. 
Gosline, W. A. (1971), Functional morphology and classification of teleostean fishes. Honolulu: The University Press of Hawaii. 208 pp.

Howard, S. T. and Byrd, T. F. (2000), The rapidly growing mycobacteria: saprophytes and parasites. Microbes and Infection., 2(15), 1845-1853.

Huizinga, H. W. and Nadakavukaren, M. J. (1997), Cellular response of goldfish, Carassius auratus (L.), to metacercarie of Ribeiroia marini (Faust and Hoffman, 1934). Journal of Fish Diseases., 20(6), 401-408.

Luna, L. G. (1992), Histopathologic methods and color atlas of special stains and tissue artifacts. Maryland: Jhonson Printers, pp.88-312.

Mariano, M. (1973), Sobre a origem e algumas propriedades das células gigantes inflamatórias. Tese de Livre-Docência, University of São Paulo, Sao Paulo, Brazil. 37pp.

Matushima, E. R. (1994), Avaliação do processo inflamatório crônico granulomatoso induzido experimentalmente através da inoculação de BCG em peixes da espécie Oreochromis niloticus - Tilápia do Nilo. PhD Thesis, University of São Paulo, Sao Paulo, Brazil. 120pp.

Metchnikoff, E. (1968), Lectures on the comparative pathology of inflammation. New York: Dover Publication. 223pp.

Momotani, E.; Kubo, M.; Ishikawa, Y.; Matsubara, Y.; Nakajima, Y. and Yioshino, T. (1993), Immunohistoquemical distribution of S100 alphapositive cells in bovine mycobacterial and nonmycobacterial granulomas. Journal of Comparative Pathology., 108(3), 291-301.

Muller, H. and Takeshita, M. (1991), In situ immunophenotype of macrophages and lymphocytes in granuloma formation of tuberculous lynphadenitis in HIV- infected and immunocompetent patients. Research in Virology., 142(2-3), 159-172.

Nash, K. A.; Fletcher, T. C. and Thomson, A. W. (1986), Migration of fish leucocytes in vitro: the effect of factors wich may be involved in mediating inflammation. Veterinary Immunology and Immunopathology., 12(1-4), 83-92.
Noga, E. J.; Dykstra, M. J. and Wright, J. F. (1989), Chronic inflammatory cells with epithelial cell characteristics in teleost fishes. Veterinary Pathology., 26(5), 429-437.

Pulsford, A. and Matthews, R. A. (1991), Macrophages and giant cells associated with a microsporidian parasite causing liquefaction of the skeletal muscle of the Norway pout, Trisopterus esmarkii (Nilsson). Journal of Fish Diseases., 14(1), 67-78.

Radhakrishman, V. V.; Mathai, A.; Radhakrishman, N. S.; Rout, D. and Sehgal, S. (1991), Immunohistochemical demonstration of mycobacterial antigens in intracranial tuberculoma. Indian Journal of Experimental Biology., 29(7), 641644.

Rego, A. A. M. S. (1999), Avaliação histológica, imunohistoquímica, ultraestrutural e filogenética da resposta inflamatória induzida experimentalmente pelo BCG em peixes do gênero Poecilia (Molinésia). MSc Thesis, University of São Paulo, Sao Paulo, Brazil. 105pp.

Talaat, A. M.; Trucksis, M.; Kane, A. S. and Reimschuessel, R. (1999), Pathogenicity of Mycobacterium smegmatis to goldfish, Carassius auratus. Veterinary Microbiology., 66(2), 151-164.

Xavier, J. G.; Matushima, E. R. (1993), Estudo comparado do processo inflamatório em teleósteos: inflamação crônica induzida por BCG em Corydora nattereri. Paper presented at $7^{\text {th }}$ Annual Meeting of Experimental Biology Society Federation, Caxambu, MG, Brazil, p.22.
Received: May 12, 2006; Revised: July 26, 2007; Accepted: March 07, 2008. 